\section{Popper on Schrödinger}

SIR-I have read, somewhat unwillingly, P.W. Atkins' review of a biography of my late friend Erwin Schrödinger, which appeared under the title "Physicist and philanderer" (Nature 341, 193; 1989). I should be grateful if you would print this defence of a great man against the accusation of cowardice ("Schrödinger also appears to have been a coward . . .").

I do not know and I do not care who originated the accusation. But the accusation is absurd, as I will show. It illustrates how some people fail to understand the situation that prevailed in Germany and in Austria under Hitler.

Atkins writes of Schrödinger: "After fittingly succeeding Max Planck in Berlin in 1927, he (a Protestant) escaped to Oxford in 1933". This is a suggestio falsi: Schrödinger did not 'escape' from the Nazis, as did so many scientists (and others) who had been dismissed and who were threatened by a fate worse than dismissal. On the contrary, like Planck, von Laue and Heisenberg, Schrödinger was, in Hitlerian terminology, an 'Aryan', and like them he could have stayed in his position in Berlin and enjoyed wealth, power and influence. He did nothing of the sort. He gave up his position as the leading physicist in Berlin, and he chose, very soon after the dismissals had started in 1933, to join his 'non-Aryan' colleagues of his own free will. He did so with a public declaration expressing his disgust with Nazism.

Owing to the help of Professor Frederick Lindemann (later Lord Cherwell), he came to Oxford where I visited him in 1935 and 1936. I found him intensely unhappy. He was grateful to the powers that had made his reception at Oxford possible. But he was particularly unhappy about the scientific atmosphere there (or rather about the complete lack of it). He was not, of course, exclusively interested in physics: he was also very interested in classical scholarship. But he complained that, in Oxford, no serious discussion about scientific or scholarly problems was possible. It just was not 'done'. It was regarded as banausic. Instead, one gossiped about people - usually running them down - and often rejected them in spite of their obvious competence and devotion to their subject. Schrödinger rejected this kind of snobbery (as did Churchill); and some silly people interpreted his open rejection (the openness of an apparent refugee) as ingratitude towards Oxford, and even towards England, which Schrödinger loved. That he ever "abused" Lindemann, or that he showed him "ingratitude", I regard as absolutely impossible. But Schrödinger was unused to dissembling, was highly temperamental and even a bit irascible.
And, as I know only too well from many discussions I had with him, he did not suffer fools gladly. But at the same time he was ready to make amends by showing special kindness. To say that he "considered himself to be God" is again absurd: he was very conscious of being far too frequently in the wrong, even morally.

During my visits to Oxford, when Schrödinger told me of his unhappiness, he also mentioned that he might leave Oxford and accept a chair in Austria which, in those days, was ruled by Schuschnigg who tried to keep the Nazis down. I implored Schrödinger to give up this mad idea. I told him that I was trying to leave Austria because Schuschnigg, who was after all a dictator like Mussolini and Hitler, was bound to succumb to Hitler. But Schrödinger thought that the allies would not let Hitler annex Austria - nor would Mussolini; and he said that, after all, if Hitler were to endanger Austria, he would emigrate again.

Not very long after this, I heard from Hans Thirring (my teacher in theoretical physics) that Schrödinger had declined Thirring's offer to vacate, in his favour, the chair in Vienna for a vacant chair in Graz, but that Schrödinger had himself accepted another chair in Graz.

In 1938, Hitler invaded Austria after a crisis of only a few days which left Schrödinger no time to escape (this time, the term 'escape' is appropriate). Being a known opponent of Nazism, he was at once in great danger. He was forced (like Galileo) to recant his anti-Nazi views; but being a little younger than Galileo was at the time, he managed an adventurous escape: he put a small suitcase with his most important documents into his old car and drove to the Italian frontier, where he left his car standing in a side road and crossed the frontier with his wife on foot. Once on the Italian side, he took a train to Rome. There he telephoned Dublin, trying to contact Eamonn De Valera, the Irish prime minister, who had invited him before. De Valera, he found out, was in Geneva. So he rang Geneva and, with some difficulty, reached him. He told him about his situation, and that his money was running out rapidly while he was telephoning. De Valera said he should at once take a train to Geneva. On the Italian-Swiss border, Schrödinger and his wife Annemarie were stopped by the carabinieri: they were forced to get out of the train, which left without them. They thought that the Nazis had alerted the

Letters submitted for Correspondence
Italian fascists. They were both searched, but they were allowed to continue by a later train. (It turned out that because they had hardly any money on them, they had been suspected of trying to export money illegally.) Once across the border they were safe.

Some of my ('Aryan') friends in Austria managed to leave under tragic and dangerous circumstances. One of my closest friends, Otto Haas, a lieutenant in Hitler's army during the war, tried to organize a resistance movement and was hanged in 1944.

Some of my friends made their peace with Nazism. They were in danger for they had been Judengenossen (associates of Jews). Who is to blame them? Who is to call them cowards?

But Schrödinger was not one of them: he left Austria soon after its annexation under the most dangerous circumstances, even though he would have been welcomed by the Nazis had he recanted. Galileo did recant. Who dares to call him a coward?

A last remark on poetry, on What is Life?, and all that.

When in 1927 I first read Schrödinger's Abhandlungen zur Wellenmechanik, I was overwhelmed, not merely by the beauty of his theory, but by the sheer poetry of it: I knew then that he was a real poet. When, long after his death, I read some of his poems, I remembered, and felt confirmed in my opinion.

When I read, 40 years ago, What is Life?, I was greatly excited. But I soon realized that this was a kind of manifesto without much content; that Schrödinger the poet had run away with Schrödinger the scientist. After all, he was inspired by the views of Max Delbrück, and the book was meant as a popularization of Delbrück's ideas. (Schrödinger's own suggestion that what characterized a living organism was that it sucked up negentropy was not to be taken seriously, for every washing machine does that, without coming to life.) However, the book worked as a biologist's manifesto, and inspired many young people: no doubt, Schrödinger's poetic powers succeeded where, as I believe, his biology failed. Here, as everywhere else, I disagree with your reviewer. (But I largely agree with Linus Pauling, and more or less with Max Perutz, in their contributions to Schrödinger, edited by C. W. Kilmister, which was published by Cambridge University Press in 1987.)

A last word: gossip about Schrödinger's philandering is not my business; nor, I suggest, is it anybody else's business. And I find it hard to swallow that Annemarie Schrödinger is being made part of the gossip. should be typed, double-spaced, on one side of the paper only.

136 Welcomes Road, Kenley, Surrey CR2 $5 \mathrm{HH}$, UK

KARL POPPER

NATURE · VOL $342 \cdot 23$ NOVEMBER 1989 